\title{
KOMPETENSI TIK DAN KEHUMASAN ASN PEMERINTAH PROVINSI SULAWESI SELATAN, SULAWESI TENGGARA, MALUKU, DAN PAPUA
}

\author{
ICT AND PR COMPETENCIES OF FUNCTIONARIES OF SOUTH \\ SULAWESI, SOUTH EAST SULAWESI, MALUKU, AND PAPUA \\ PROVINCIAL GOVERNMENTS
}

\author{
Darman Fauzan Dhahir \\ Balai Besar Pengembangan SDM dan Penelitian Komunikasi dan Informatika Makassar \\ email: darm007@kominfo.go.id
}

\begin{abstract}
Abstrak
Penelitian ini bertujuan untuk memotret profil dan kompetensi Aparatur Sipil Negara (ASN) bidang Teknologi informasi dan Komunikasi (TIK) dan Kehumasan Provinsi Sulawesi Selatan, Sulawesi Tenggara, Maluku, dan Papua. Penelitian ini menggunakan pendekatan kuantitatif dan kualitatif. Pengumpulan data dilakukan dengan metode survey pada 280 responden, wawancara pada 50 informan dan Focus Group Discission (FGD) di empat provinsi pada Tahun 2018. Data dikumpulkan, disajikan, dan dideskripsikan dengan teknik analisis interaktif. Hasil penelitian menunjukkan bahwa rata-rata ASN bidang TIK dan Kehumasan pada wilayah yang diteliti memiliki jenjang pendidikan S1 dan berusia relative muda. Mayoritas mereka adalah Pejabat Fungsional Umum, bukan Pejabat Fungsional Tertentu. Pengalaman kerja mereka dalam bidang masing-masing beragam, yakni: kurang dari 1 tahun hingga lebih dari 10 tahun. ASN Bidang TIK mengerjakan pekerjaan Perkantoran, dengan menggunakan aplikasi pengolah kata dan angka dan presentasi. ASN kehumasan dominan menggunakan aplikasi pengolah kata. Lebih dari setengah ASN dalam dua bidang tersebut belum pernah mengikuti pelatihan dalam bidangnya, sehingga hanya sedikit yang memiliki sertifikat kompetensi. Kemampuan ASN yang diteliti berada rentang level 'pemula' hingga 'mampu'. Upayaupaya yang telah dilakukan oleh pemerintah provinsi belum banyak, namun masing-masing ASN telah berusaha untuk dapat bekerja dengan baik dengan cara belajar secara otodidak. Pemerintah Provinsi yang diteliti mengaku membutuhkan dukungan dari pemerintah pusat dalam rangka meningkatkan kemampuan TIK dan Kehumasan ASN.
\end{abstract}

Kata Kunci: ASN, Kawasan Timur Indonesia, kompetensi, kehumasan, TIK.

\begin{abstract}
This study aims to capture the profile and competence of functionaries in the fields of Information and Communication Technology (ICT) and Public Relations in South Sulawesi, Southeast Sulawesi, Maluku, and Papua Provinces. Current research uses quantitative and qualitative approaches. Data collection was carried out by survey methods on 280 respondents, interviews with 50 informants and FGD in four provinces in 2018. Data were collected, presented, and described using interactive analysis techniques. The results showed that on average, the functionaries studied had an undergraduate education level and were relatively young. The majority of them are General Functional Officials, not Specific Functional Officials. Their work experience in their respective fields varies from less than 1 year to more than 10 years. ICT functionaries do office work, using word, numbers, and presentation processing applications. Public relations functionaries, predominantly use word processing applications. More than half them have never attended training in their respective fields, so
\end{abstract}


only a few of them who have competency certificates. Their competencies have been measured in the range of 'beginner' to 'capable' levels. The efforts that have been made by the provincial government have not been many, but each the functionaries has tried to be able to work well by self-taught learning. The Provincial Governments' person in charge admitted that they need support from the central government in order to improve the ICT and Public Relations competencies of the functionaries.

Keywords: Government officials, Eastern Indonesia, competence, public relations, ICT.

\section{PENDAHULUAN}

Kehadiran TIK membawa perubahan pada seluruh aspek kehidupan manusia. Pesatnya perekembangan inovasi di bidang TIK telah menyebabkan iklim kehidupan semakin kompetitif, terbuka, cepat, tepat, efisien dan efektif melalui $e$-life seperti $e$ commerce, e-government, e-education, elearning, e-library, e-procurement, ejournal, e-medicine, e-bodiversity, ebudgeting, e-planning, e-musrenbang, ekinerja, e-kemiskinan, e-reporting, espacial dan lainnya.

Teknologi Informasi dan Komunikasi berperan sebagai enabler technology dalam upaya pemerintah untuk meningkatkan kualitas hidup dan pembangunan masyarakat yang dilakukan melalui $e$ government. Sachs dalam artikel Data for Development menyatakan bahwa melalui GIS (Geographic Information System), perkembangan pemerintah daerah di wilayah pinggiran dan terpencil pun dapat dimonitor secara real time. Teknologi juga mampu meningkatkan kemampuan pemerintah untuk memberikan pelayanan yang prima dan memangkas birokrasi yang rumit (Sachs, 2015). Perkembangan tata kelola elektronik juga diharapkan dapat memberikan energi kepada birokrat agar bertindak lebih gesit, lincah dan merubah pola pikir lama karena selama ini disinyalir birokrasi yang ada bersifat lambat dan hanya menjalankan business as usual semata (Lauranti et al., 2017).

E-government adalah hal mutlak yang diperlukan untuk mencapai sukses pemerintahan terbuka. Hal ini tercermin dari upaya pemerintah melalui peraturan: (a). UU No. 12 tahun 2008 tentang Keterbukaan Informasi Publik, (b). UU no. 37 tahun 2008 tentang Ombudsman Republik Indonesia, (c). UU Nomor 25 tahun 2009 tentang Pelayanan Publik, (d). Peraturan Kementerian Dalam Negeri No. 35 tahun 2010 tentang Pedoman Pengelolaan Informasi di Kemendagri dan Pemda serta (e). Peraturan Pemerintah No. 61 tahun 2010 tentang Pelaksanaan UU No. 14 tahun 2008.

Inovasi yang dikembangkan dalam praktik e-government seharusnya dapat menyelesaikan persoalan khas yang dimiliki oleh setiap daerah (Lauranti et al., 2017), tentunya hal ini disesuaikan dengan potensi dan kapasitas Aparatur Sipil Negara yang ada di daerahnya tersebut, merujuk 
pada Undang-undang Nomor 25 tahun 2004 tentang Sistem Perencanaan Pembangunan Nasional (SPPN) yaitu membentuk tata kelola pemerintah yang transparan, akuntabel, partisipatif, inovatif, serta merujuk pada RPJMN 2015-2019 yang mengamanatkan dua strategi utama yaitu (1) membangun keterbukaan informasi public dan (2) mendorong masyarakat untuk dapat mengakses informasi public dan memanfaatkannya (Rencana Aksi Nasional Keterbukaan Pemerintah 2016-2017, 2016).

Jika melihat pada capaian EGDI (EGovernment Development Index) yaitu pemeringkatan yang dilakukan oleh Perserikatan Bangsa-Bangsa, dalam rangka penilaian yang mencakup 3 dimensi yaitu online service index, telecommunication infrastructure index serta the human capital index untuk melihat apakah aktivitas lembaga publik sudah lebih efektif, efisien, transparan dan akuntabel maka Indonesia masih memiliki pekerjaan rumah yang banyak karena Indonesia berada pada peringkat ke 106. Bahkan peringkat Indonesia masih tertinggal ketika diperbandingkan dengan Negara-negara tetangga yang berada di lingkup Asia Tenggara seperti Malaysia pada peringkat ke 60, Filipina pada peringkat ke 71, Brunai Darussalam pada peringkat ke 83 (Sisil, 2017).
Pencapaian tujuan strategis $e$ government dilaksanakan melalui enam strategi yang tertuang dalam Inpres No. 3 tahun 2003 tentang Kebijakan dan Strategi Nasional Pengembangan E-Government salah satunya yaitu mengembangkan Kapasitas SDM baik pemerintah maupun pemerintah daerah otonom disertai dengan meningkatkan e-literacy masyarakat (Widowati, 2017).

Pentingnya pengembangan kapsitas SDM baik di pemerintah pusat maupun pemerintah daerah dalam rangka mendukung e-government sangat dibutuhkan karena manusia adalah kunci. Terdapat urgensi untuk melakukan pemetaan kompetensi TIK ASN saat ini dikarenakan banyaknya kendala di tataran praktek dalam mengembangkan program $e$ government.

Deputi Inovasi Lembaga Administrasi Negara (LAN), Dr Tri Widodo Utomo, menyatakan bahwa kalangan Aparatur Sipil Negara (ASN) masih minim dalam penguasaan terhadap TIK, selain itu Literasi IT di kalangan birokrat belum merata. ASN yang sudah berumur, dan terutama berada di daerah pelosok, masih cukup banyak yang mengalami gagap teknologi (digital divided) padahal tingkat literasi TIK pada ASN sangat diperlukan dalam pengembangan maupun implementasi $e$ - 
Goverment di masa yang akan datang (Berita Satu, 2016).

Selain itu, kemampuan TIK ASN yang berstatus PNS kurang memadai (Haryati, 2017; Suroto, 2017), padahal tuntutan terhadap kemampuan TIK. Demikian pula, ASN yang yang ditempatkan sebagai SDM TIK belum tentu berlatar pendidikan TIK, sebab sering terjadi ketidakserasian antara penempatan ASN dan kompetensi pendidikannya (Batita et al., 2017; Siswanto, 2020).

Oleh karena itu, dibutuhkan data secara nasional yang dapat menunjukkan tingkat literasi TIK di kalangan Aparatur Sipil Negara, terutama wilayah timur Indonesia yang lebih tertinggal dibandingkan wilayah barat (Maryati, 2015; Prasetyo \& Firdaus, 2009).

Di samping itu, akhir-akhir ini kita dihadapkan pada banyaknya sumber informasi yang tidak kredibel namun memberi pengaruh cukup besar terhadap persepsi masyarakat. Informasi-informasi yang bersifat hoax dari sumber yang tidak jelas kerapkali diakses oleh khalayak melalui media sosial (Juditha, 2018). Informasi-informasi yang cenderung negatif bagi pemerintah atau bahkan bertolak belakang dari kenyataan yang sebenarnya terlihat lebih dominan dibanding informasi positif atas kinerja pemerintah yang sesungguhnya (Syahputra, 2017).
Presiden pernah mengeluarkan Inpres No. 9 tahun 2015 tentang Pengelolaan Komunikasi Publik, yang di tandatangani pada tanggal 25 Juni 2015 yang bertujuan menyerap aspirasi dan mempercepat penyampaian informasi tentang kebijakan dan program pemerintah. Akan tetapi, dalam praktiknya, narasi tunggal pemerintah kerap berantakan akibat tidak bekerja optimalnya Pranata Humas atau Governement Public Relation yang dimiliki dan dioperasionalkan kementerian, lembaga dan pemerintah daerah (Heryanto, 2018).

Efektifitas tata kelola komunikasi publik pemerintah masih dipertanyakan oleh beberapa pihak karena banyak hal yang tidak tersampaikan secara sistematis, komunikatif dan komprehensif guna membangun pemahaman bersama antara pemerintah dan khalayak luas (Kusumawati et al., 2019). Hal ini tidak lepas dari lambatnya humas pemerintah dalam koordinasi dan pengelolaan suatu isu (Mukhroman et al., 2014). Kenyataan ini bisa jadi disebabkan oleh kompetensi humas pemerintah yang memamg belum memadai untuk menjawab setiap isu yang muncul.

Oleh karena itu juga diperlukan pemetaan kompetensi SDM Humas pemerintah berserta kendala-kendala yang dihadapinya dalam rangka perbaikan kinerja humas pemerintah. 
Data yang di hasilkan dari penelitian ini dapat digunakan sebagai fondasi dalam membuat kebijakankebijakan yang bersifat afirmatif untuk meningkatkan kemampuan ASN di bidang TIK dan Kehumasan. Penelitian ini juga dapat menjadi acuan program pengembangan dan rekruitmen ASN di bidang TIK dan Kehumasan.

\section{METODE PENELITIAN}

Penelitian ini menggunakan pendekatan campuran kualitatif dan kuantitatif paralel konvergen, yaitu penelitian kualitatif dan kuantitatif yang dilakukan secara bersamaan untuk memperoleh analisis yang menyeluruh (Creswell, 2015).

Obyek penelitian pada kajian ini dikelompokkan atas ASN Bidang TIK dan ASN Bidang Kehumasan.

ASN Bidang TIK adalah ASN yang bekerja pada SKPD Provinsi yang seharihari diberi tanggungjawab dalam pengoperasian komputer, mendesain dan/atau memelihara web, jaringan, multimedia, keamanan jaringan dan lainlain sejenisnya, dengan latar belakang pendidikan TIK maupun bukan.

ASN Bidang Kehumasan adalah ASN yang bekerja pada SKPD Provinsi yang sehari-hari bertugas sebagai dalam bidang kehumasan dengan latar belakang Pendidikan terkait kehumasan maupun bukan
ASN yang dimaksud tidak terbatas pada PNS dengan Jabatan fungsional Pranata Humas ataupun Pranata Komputer, melainkan jabatan apapun yang mengerjakan pekerjaan bidang TIK dan bidang Kehumasan dalam instansi yang diteliti. ASN yan menjadi responden/Informan berasal dari 9-10 Satuan Kerja Pemerintah Daerah (SKPD) Pemerintah Provinsi yang diteliti.

Penelitian ini dilaksanakan di 4 provinsi, yakni: Maluku (Zona 1), Papua (Zona 2), Sulawesi Selatan (Zona 3), dan Sulawesi Tenggara (Zona 4).

Informasi yang dikumpulkan dari ASN bidang TIK, antara lain: tingkat kompetensi SDM TIK untuk ASN Provinsi pada keahlian-keahlian khusus, seperti Jaringan, Web, Pemrograman, Desain Grafis, Multimedia dan sebagainya. Termasuk didalamnya informasi seberapa besar kebutuhan pemerintah provinsi akan keahlian-keahlian tersebut, kendalakendala yang dihadapi oleh ASN bidang TIK dan harapan mereka akan pengembangan kemampuan TIK.

Informasi yang dikumpulkan dari ASN bidang Kehumasan, antara lain: tingkat kemampuan SDM kehumasan dalam mengumpulkan, mengelola dan menyebarluaskan informasi yang berasal dan atau melalui media cetak, media elektronik, media sosial, media online dan media lainnya. 
Informasi yang dikumpulkan dari pengelola pemerintah daerah berupa rencana strategis pemerintah provinsi dalam pengembangan TIK dan Kehumasan ke depan, kendala yang dihadapi, upaya yang telah dilakukan, dan harapan-harapan.

Data yang dikumpulkan merupakan data primer yang diperoleh langsung dari responden baik melalui riset kuantitatif maupun kualititatif. Data primer untuk riset kuantitatif diperoleh melalui survei sedangkan untuk data kualitatif diperoleh melalui FGD dan wawancara mendalam

Wawancara mendalam dilakukan untuk mendapatkan informasi mendalam untuk mencapai tujuan penelitian. Wawancara yang dilakukan adalah wawancara semi terstruktur dengan menggunakan panduan wawancara, namun tidak tertutup kemungkinan pengembangan pertanyaan selama wawancara berlangsung. Wawancara dilakukan secara tatap muka terhadap 50 informan yang juga merupakan bagian dari responden kuantitatif. Mereka yang dipilih menjadi informan dinilai memiliki pengetahuan dan kemauan untuk menberikan informasi lebih dalam terkait masalah penelitian.

FGD dilakukan dengan maksud mendapatkan informasi mengenai rencana strategis pemerintah daerah dalam pengembangan ASN bidang TIK dan Kehumasan, kendala-kendala yang dihadapi, serta harapan mereka terkait masalah penelitian. Peserta FGD adalah Bappeda, Diskominfo dan Badan Kepegawaian Daerah, Biro Humas Sekretariat Daerah ditambah 5 (lima) perwakilan SKPD lainnya yang diperoleh secara random. Sementara itu, data kuantitatif diperoleh melalui survei terhadap 200 responden ASN TIK dan 80 responden Kehumasan.

Penentuan responden menggunakan multi stage stratified random sampling, yakni pengambilan sampel melalui proses pembagian populasi ke dalam strata, memilih sampel acak sederhana dari setiap stratum, dan menggabungkannya ke dalam sebuah sampel untuk menduga parameter populasinya (Yamane, 1973).

Data yang diperoleh kemudian dibersihkan sebelum dianalisis. Data cleaning dilakukan untuk mengantisipasi kesalahan yang masih terjadi dalam proses pengimputan data. Pendekatan analisis data yang digunakan adalah analisis data interaktif, dan analisis statistika deskriptif.

\section{HASIL DAN PEMBAHASAN}

Berdasarkan hasil FGD, terungkap bahwa ASN yang bertugas di bidang TIK dan Kehumasan tidak terdata dengan baik oleh BKD di semua wilayah provinsi yang diteliti, sebab penugasan ASN tergantung perintah dari pimpinan masing-masing SKPD. Perwakilan BKD Provinsi Maluku mengungkapkan dalam FGD: “... setiap 
tahun, kami prioritaskan CPNS bidang TIK, namun masalahnya, kebanyakan alumni TIK yang direkrut menjadi PNS malah ditempatkan di bidang administrasi. Untuk bidang kehumasan, saat (kami) ini tidak bisa memberikan data pasti. Secara umum, pelaksanakan kehumasan di setiap OPD sudah berjalan, hanya saja belum dapat kami petakan."

ASN sendiri merasakan minimnya jumlah ASN bidang TIK dan kehumasan. Sebanyak 11 informan yang merupakan ASN bidang TIK mengungkapkan hal tersebut. Salah satu informan dari Porvinsi Maluku menyatakan bahwa 20 orang ASN bidang TIK dari total 128 pegawai yang bekerja pada instansinya, belum mencukupi kebutuhan institusi. Sebagian lainnya, misalnya salah satu informan dari Provinsi Sulawesi Tenggara, berpendapat bahwa jumlah ASN secara kuantitatif sudah relatif banyak, namun kompetensi mereka masih kurang.

\section{ASN Bidang TIK}

Berdasarkan survey yang dilakukan pada 200 ASN bidang TIK di empat provinsi, ASN bidang TIK didominasi oleh ASN yang berlatar pendidikan S1, yakni sebesar 129 orang (64,5\%). Sisanya, yang berlatar belakang S2 berjumlah 37 orang (18,5\%), SLTA berjumlah 20 orang (10\%), Diploma berjumlah 14 orang (7\%), dan belum ada yang S3 (0\%). Jika dilihat dari kondisi ini, ASN yang menangani bidang
TIK seharusnya dapat kategorikan sebagai orang-orang yang kompeten, sebab setidaknya mereka adalah para sarjana. Sayang, banyak dari mereka yang ditugaskan pada bidang tersebut yang bukan sarjana TIK. Dari 200 ASN bidang TIK yang menjadi responden, hanya 29 orang $(14,5 \%)$ yang berlatar belakang pendidikan TIK. Hal tersebut juga terungkap dalam FGD dan wawancara yang dilaksanakan di seluruh provinsi yang menjadi lokasi penelitian. Salah satu narasumber FGD di Sulawesi Selatan mengakui bahwa dari 105 PNS di instansi tempat ia bekerja, tidak ada satupun yang berlatar belakang pendidikan TIK. Akibatnya, kemampuan TIK mereka sangat minim. Menurutnya, ASN yang memiliki kemampuan TIK yang cukup memadai kebanyakan dari unsur PTT atau honorer. Informan dari Dinas PUPR Provinsi Maluku beralasan bahwa latar belakang pendidikan TIK tidak terlalu diperhatikan dalam sebuah penugasan/penempatan pekerjaan TIK, karena kemampuan teknis bidang (sesuai fungsi institusi) lebih diutamakan. Alasan tersebut semakin kuat dengan pernyataan Informan dari Dinas Kelautan dan Perikanan Provinsi Maluku: "100\% ASN TIK di DKP dapat mengoperasikan komputer, walaupun yang berlatar belakang pendidikan TIK hanya 1 orang, itupun masih berstatus honorer." 
Berdasarkan usia, kebanyakan ASN bidang TIK berusia muda. Usia pensiun mereka relatif masihlama. Sebanyak 95 responden (47,5\%) ASN bidang TIK berusia 31-40 tahun dan 48 responden (24\%) berusia dibawah 30 tahun, berarti total yang berumur 40 tahun ke bawah adalah $71,5 \%$. Sementara itu, yang berumur 41-50 tahun berjumlah 46 responden (23\%) dan yang berumur 51 tahun ke atas hanya berjumlah 11 responden $(5,5 \%)$.

Sebagian besar ASN yang ditugaskan di bidang TIK adalah Fungsional Umum, yakni sebanyak 123 responden (61,5\%). Pejabat Struktural yang diserahi tanggungjawab bidang TIK berjumlah 65 responden $\quad(32,5 \%)$. Sementara itu, Pejabat Fungsional Tertentu yang bertindak sebagai tenaga TIK berjumlah 11 responden (5,5\%). Itupun, tidak ada saru Pejabat Fungsional Tertentu pun yang merupakan fungsional TIK, melainkan Peneliti, Perekayasa, Arsiparis, dan Penerjemah yang diserahi tanggung jawab pekerjaan TIK.

Pengalaman para responden ditugaskan dalam bidang TIK beragam dan jumlahnya relatif merata. Ada yang bertugas kurang dari satu tahun, ada pula yang di atas 10 tahun. ASN yang memiliki pengalaman kerja di Bidang TIK 3-5 tahun adalah yang terbanyak dengan jumlah 55 responden (27,5\%). Sementara itu, yang memiliki pengalaman 1-2 tahun berjumlah
47 responden $(23,5 \%)$, yang memiliki pengalaman 6-10 tahun berjumlah 42 responden $(21 \%)$, dan yang memiliki pengalaman di bawah 1 tahun berjumlah 21 responden (10,5\%). Jumlah terkecil adalah ASN bidang TIK yang memiliki pengalaman lebih dari 10 tahun, yakni 24 responden $(12 \%)$.

Pekerjaan yang paling sering dikerjakan oleh ASN bidang TIK adalah yang pekerjaan yang berhubungan dengan aplikasi perkantoran dengan jumlah mencapai 147 responden (73,5\%). Pekerjaan bidang TIK lain hanya maksimal dilakukan oleh sekitar $20 \%$ responden, yaitu bidang jaringan komputer sebanyak 44 responden (22\%), bidang multimedia 39 (19,5\%), bidang lainnya 35 responden (17,5\%), dan bidang software Development 13 responden $(6,5 \%)$.

Sejalan dengan pekerjaan yang paling sering dikerjakan oleh ASN bidang TIK berupa pekerjaan perkantoran, aplikasi yang paling sering digunakan pun adalah aplikasi pengolah kata, angka dan presentasi. Sebesar 119 responden (59,5\%) menggunakan aplikasi pengolah kata, 100 responden (50\%) menggunakan aplikasi pengolah angka, dan 62 responden (31\%) menggunakan aplikasi pengolah presentasi. Sementara itu, pengguna aplikasi multimedia hanya 40 responden (20\%), aplikasi desain sebanyak 32 responden (16\%), aplikasi pemrograman sebanyak 30 
responden (15\%), dan aplikasi lainnya, seperti sistem informasi kepegawaian, keuangan, perencanaan, pengadaan barang/jasa, dan pemetaan sebanyak 24 responden $(12 \%)$.

\section{Undang-Undang}

ASN

mengamanatkan bahwa setiap pegawai memiliki hak dan kesempatan untuk mengembangkan kompetensi, yakni meliputi kompetensi teknis yang diukur dari tingkat dan spesialisasi pendidikan, pelatihan teknis fungsional, dan pengalaman bekerja secara teknis. Akan tetapi, berdasarkan surbey, lebih dari separuh ASN bidang TIK pada provinsi yang diteliti (65\%) tidak pernah mengikuti pelatihan bidang TIK. Hal ini diakibatkan oleh berbagai faktor. Di dalam FGD dan wawancara, banyak yang mengemukakan bahwa kesempatan ASN untuk mendapatkan pelatihan, terutama teknis bidang TIK, sangat kecil, sebab jumlah pelatihan dan kuota yang jauh lebih sedikit daripada jumlah ASN yang memerlukannya. Bahkan, sebagian provinsi yang selama ini hanya mengharapkan pemerintah pusat untuk menyelenggarakan pelatihan, sebagaimana diungkapkan oleh salah satu narasumber FGD: "diharapkan (pada) kementerian (Kominfo), selain memberikan pelatihan, (sebaiknya) kami juga diberikan pendampingan, misalnya kami diberi tim ahli untuk beberapa bulan mendampingi selama proses pembelajaran TIK." Alasannya adalah terbatasnya anggaran dan tenaga pendidik lokal bidang TIK. Narasumber tersebut mngungkapkan: "Badan Diklat yang ada memang belum menyentuh bidang TIK untuk (peningkatan) kemampuan SDM lokal, itu dikarenakan tenaga pengajar bidang TIK juga masih sangat sedikit di wilayah ini, sementara untuk memanggil (pengajar) dari luar (daerah), kami kekurangan dana." Hal tersebut diperjelas dengan pernyataan narasumber lain yang mengatakan: “...pelatihan yang ada, biasanya hanya diselenggaran dari (oleh) kementerian, bukan dari (oleh) pemda setempat." Untung saja, para ASN tidak kehilangan akal untuk mendukung terlaksananya tugas yang mereka emban. Seluruh informan menyatakan bahwa mereka belajar secara autodidak. Di samping itu, bagi yang pernah mengikuti pelatihan TIK, belum tentu memiliki sertifikat kompetensi. Berdasarkan survey, yang jumlah ASN TIK yang memiliki sertifikat kompetensi TIK hanya 37 orang $(18 \%)$, padahal yang pernah mengikuti pelatihan sebesar 71 orang (35\%).

Untuk meningkatan kompetensi ASN, kegiatan pelatihan sangat diharapkan, baik oleh Pemerintah Provinsi, maupun ASN yang diberi tugas bidang TIK. Hanya saja, karena beberapa kendala sebagaimana telah diungkapkan sebelumnya, pengelola 
ASN pada wilayah yang diteliti menyatakan dalam FGD bahwa belum sanggup memenuhi kebutuhan Diklat. Pelatihan yang paling banyak diinginkan oleh ASN bidang TIK adalah pelatihan System Administration, yakni 83 responden (41,5\%), diikuti dengan yang menginginkan pelatihan Web Design sebanyak 58 responden (29\%), Database Developer sebanyak 56 responden (28\%), Network Administration sebanyak 54 responden (27\%), Web Programmer sebanyak 50 responden (25\%), Graphic Design sebanyak 48 responden (24\%), Desktop Programming sebanyak 42 responden (21\%), Video Production sebanyak 28 responden (14\%), dan pelatihan lainnya sebanyak 8 responden $(4 \%)$.

\section{Gambar 1. Kompetensi rata-rata ASN bidang TIK (sumber: hasil olah data).}

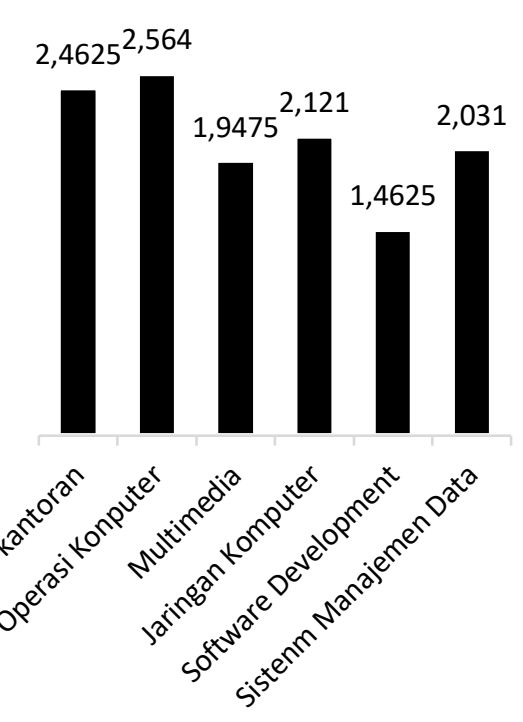

Gambar 1 menunjukkan bahwa tidak terdapat perbedaan signifikan kemampuan rata-rata ASN Bidang TIK dalam mengerjakan jenis-jenis pekerjaan TIK. Rata-rata skor kemampuan mereka berkisar antara 1,4 - 2,6. Hal tesebut menunjukkan bahwa secara rata-rata, mereka berada pada level pemula (level 1), hingga sedikit di atas level mampu (level 2). Mereka memiliki skor kemampuan sekitar 2,5 dalam jenis keahlian operasi komputer dan aplikasi perkantoran. Sebaliknya, mereka paling lemah dalam jenis pekerjaan software development dan multimedia dengan memiliki skor dibawah 2,0. Secara rinci, sebenarnya ada beberapa ASN yang memiliki kemampuan level ahli (level 4) maupun master (level 5) dalam jenis kompetensi TIK, namun sayang, jarang dari mereka yang berkenan membagi pengetahuan, sebagaimana diungkap oleh salah satu narasumber FGD: “Orang sudah terlatih tidak bersedia meng-share ilmunya ke rekan-rekan yang lain." Hal lain yang mempengaruhi adalah pelatihan yang belum memenuhi harapan, sepeti yang diungkapkan oleh salah seorang narasumber FGD: "Sudah banyak mengikuti pelatihan, akan tetapi belum bisa diaplikasikan, karena model pelatihan yang diikuti, dari segi waktu sangat singkat dan sifatnya masih pengenalan."

Dalam hal penguasaan aplikasi perkantoran, sebanyak 79 responden (39,5\%) ASN Bidang TIK menyatakan 
berada pada level mampu, sementara 54 responden (27\%) mengaku masih pemula. Responden yang cakap mengerjakan jenis pekerjaan tersebut mencapai 46 responden (23\%), sementara yang ahli hanya 15 responden $(7,5 \%)$ dan yang master hanya 6 responden (3\%). Sebenarnya, kebanyakan pekerjaan yang ditugaskan kepada mereka, dan aplikasi yang mereka gunakan seharihari adalah bidang/aplikasi perkantoran. Hal ini menunjukkan bahwa memampuan mereka yang tidak berkembang, namun mereka sudah cukup puas dengan hasil pekerjaan yang selama ini dikerjakan. Sebagian mereka beranggapan, yang dibutuhkan oleh instansi mereka saat ini, adalah kompetensi pada level tersebut. Salah satu informan menyatakan: "Untuk penempatan, itu telah sesuai dan memperhatikan kemampuan TIK, sedangkan untuk promosi (saya) belum tahu, namun sejauh ini memang (telah) dianggap cukup sesuai."

Jika dirinci berdasarkan zona sebagaimana disajikan dalam Gambar 2, jumlah ASN yang berada dalam klasifikasi level tertentu dikali dengan bobot sesuai levelnya (1-5), maka kemampuan aplikasi perkantoran ASN bidang TIK yang tertinggi ada di pada Zona 3 dengan bobot 120 , dengan rincian $1(2 \%)$ master, $8(16 \%)$ ahli, 10 (20\%) cakap, 22 (44\%) mampu dan $9(18 \%)$ pemula.

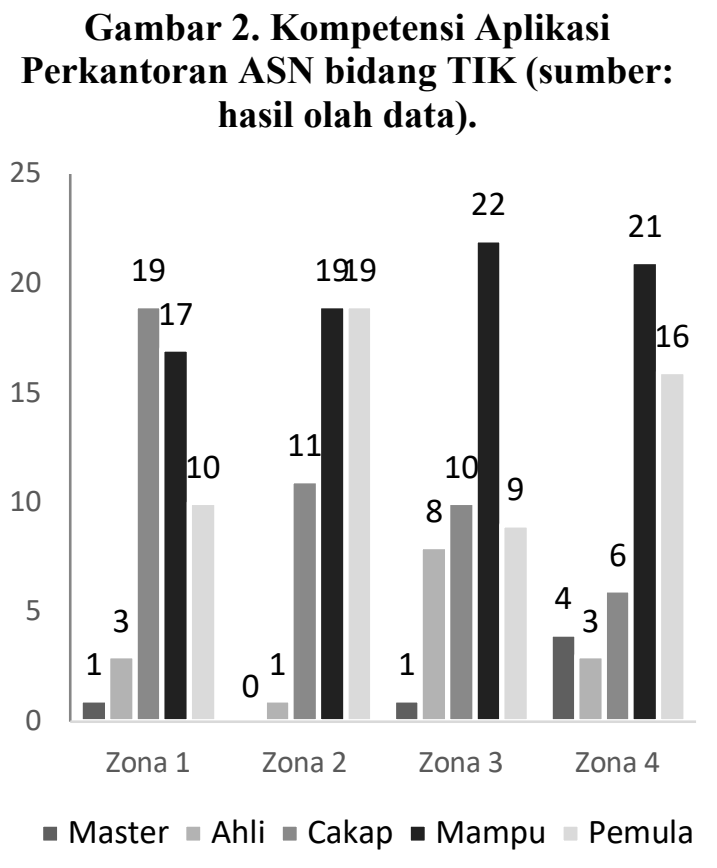

Zona 1 menyusul dengan bobot 118 . Zona 1 memiliki 1 (2\%) master, 3 (6\%) ahli, 19 (38\%) cakap, 17 (34\%) mampu dan $10(20 \%)$ pemula. ASN pada Zona 4 memiliki bobot kemampuan aplikasi perkantoran 108. Zona 4 memiliki 4 (8\%) master, 3 (6\%) ahli, 6 (12\%) cakap, 21 (43\%) mampu dan 16 (32\%) pemula. Bobot kemampuan aplikasi perkantoran yang paling rendah adalah zona 2 yang hanya mencapai 94, tanpa seorang pun master (0\%), 1 (2\%) ahli, 11 (22\%) cakap, dan masing-masing 19 (38\%) mampu dan pemula.

Berdasatkan kompetensi pengoperasian komputer, masing-masing sebanyak 65 responden $(32,5 \%)$ ASN Bidang TIK menyatakan berada pada level mampu dan pemula dalam mengerjakan jenis pekerjaan pengoperasian komputer. Responden yang cakap mengerjakan jenis 
pekerjaan tersebut mencapai 43 responden (21,5\%), sementara yang ahli hanya 19 responden $(9,5 \%)$ dan yang master hanya 8 responden $(4 \%)$.

Jika dirinci berdasarkan zona sebagaimana disajikan dalam Gambar 3, kemampuan mengoperasikan komputer ASN bidang TIK tertinggi ada di pada Zona 1 dengan bobot 118, dengan rincian $2(4 \%)$ master, 8 (16\%) ahli, 9 (18\%) cakap, 18 (36\%) mampu dan $13(26 \%)$ pemula. Zona 3 menyusul dengan bobot 114. Zona 3 memiliki 3 (6\%) master, 5 (10\%) ahli, 12 (24\%) cakap, 13 (26\%) mampu dan 17 (34\%) pemula. ASN pada Zona 2 memiliki bobot kemampuan pengoperasian komputer 108. Zona 2 memiliki $3(6 \%)$ master, 2 (4\%) ahli, 13 (26\%) cakap, 12 (24\%) mampu dan 20 (40\%) pemula. Bobot kemampuan pengoperasian komputer yang paling rendah adalah zona 4 yang hanya mencapai 102, tanpa seorang pun yang master (0\%), 4 (8\%) yang ahli, 9 (18\%) yang cakap, dan 22 (44\%) yang mampu dan 15 (30\%) yang pemula.

\section{Berdasatkan}

kompetensi

multimedia, sebanyak 114 responden (57\%) ASN Bidang TIK menyatakan masih berada pada level pemula dalam mengerjakan jenis pekerjaan pengoperasian komputer.

Gambar 3. Kompetensi pengoperasian komputer ASN bidang TIK (sumber: hasil olah data).

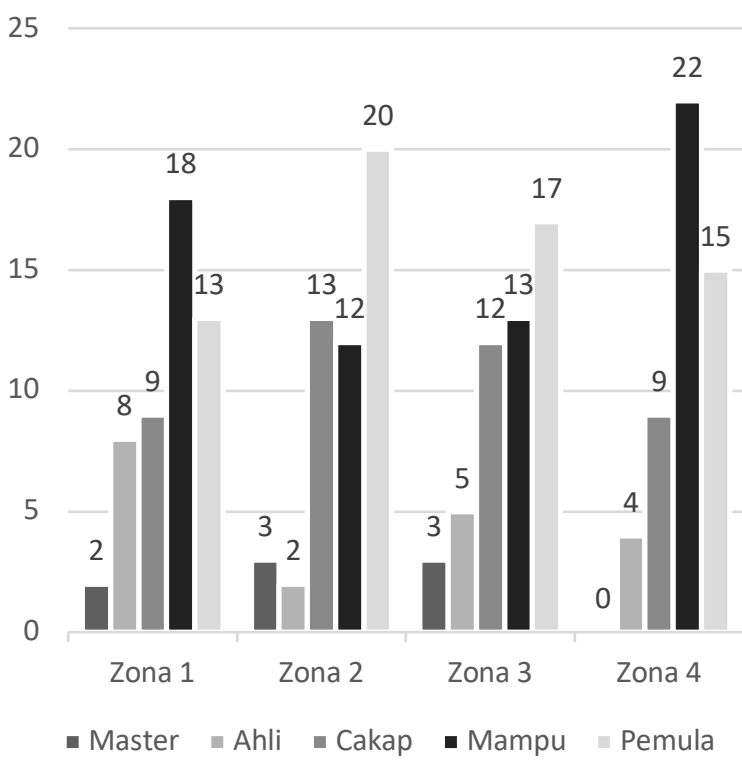

Responden yang mampu mengerjakan jenis pekerjaan tersebut sebanyak 49 responden $(24,5 \%)$, sementara yang cakap sebanyak 30 responden (15\%), yang ahli hanya 6 responden $(3 \%)$ dan yang master hanya 1 responden $(0,5 \%)$.

Jika dirinci berdasarkan zona sebagaimana disajikan dalam Gambar 4, kemampuan multimedia ASN bidang TIK yang tertinggi ada di pada Zona 1 dengan bobot 88, dengan tanpa master $(0 \%), 12$ (24\%) ahli, 3 (6\%) cakap, 11 (22\%) mampu dan $29(58 \%)$ pemula. Zona 2 menyusul dengan bobot 84 . Zona 2 tidak memiliki master (0\%), 2 (4\%) ahli, 7 (14\%) cakap, 14 (28\%) mampu dan 27 (54\%) pemula. ASN pada Zona 3 memiliki bobot kemampuan multimedia 82 . Zona 3 memiliki 1 (2\%) master, 1 (2\%) ahli, 5 (10\%) cakap, 15 (30\%) mampu dan 28 (56\%) pemula. Bobot kemampuan multimedia yang paling rendah adalah zona 4 yang hanya mencapai 
77, tanpa seorang pun master dan ahli, 7 (14\%) cakap, 13 (26\%) mampu, serta 30 $(60 \%)$ pemula.

\section{Gambar 4. Kompetensi Multimedia ASN bidang TIK (sumber: hasil olah data).}

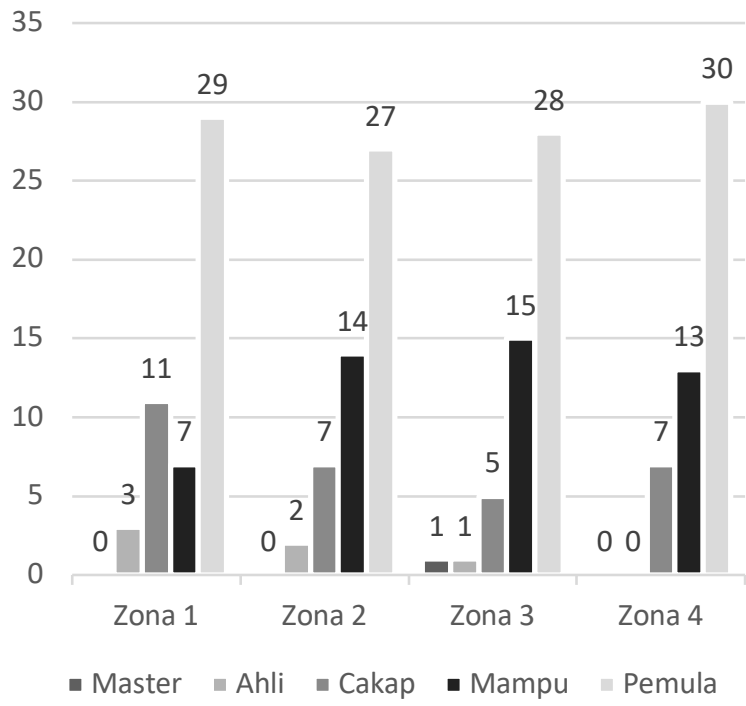

Dalam hal kompetensi jaringan computer, sebanyak 101 responden (50,5\%) ASN Bidang TIK menyatakan masih berada pada level pemula dalam mengerjakan jenis pekerjaan pengoperasian komputer. Responden yang mampu mengerjakan jenis pekerjaan tersebut sebanyak 52 responden (26\%), sementara yang cakap berjumlah 31 responden $(15,5 \%)$, yang ahli hanya 11 responden $(5,5 \%)$ dan yang master hanya 5 responden (2,5\%). Jika dirinci berdasarkan zona sebagaimana disajikan dalam Gambar 5, kemampuan jaringan komputer ASN bidang TIK yang tertinggi ada di pada Zona 1 dengan bobot 96, tanpa memiliki master
(0\%), 7 (14\%) ahli, 7 (14\%) cakap, 11 (22\%) mampu dan 25 (50\%) pemula.

\section{Gambar 5. Kompetensi Multimedia ASN bidang TIK (sumber: hasil olah data).}

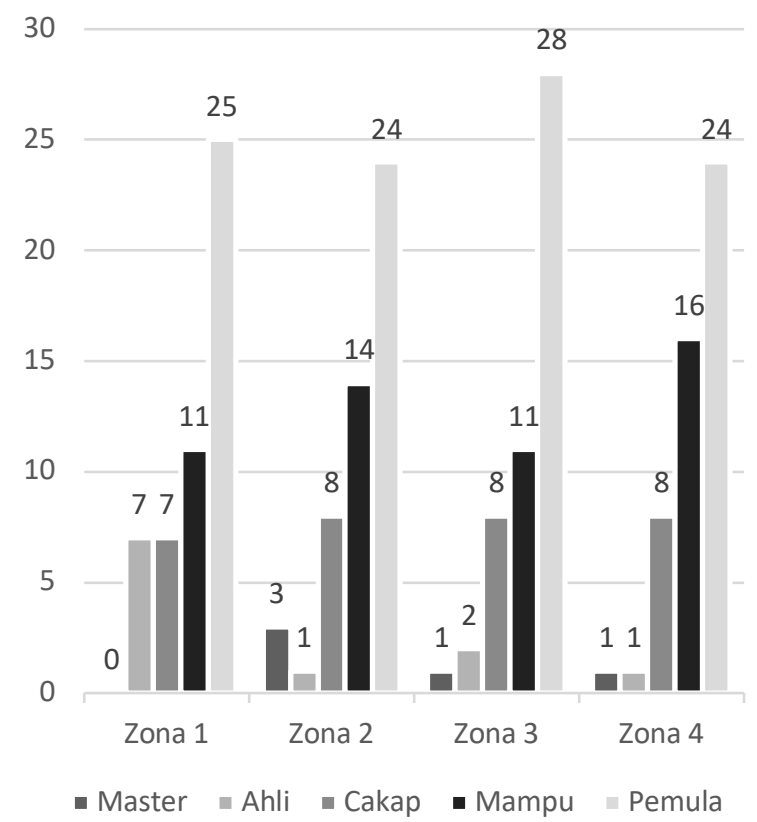

Zona 2 menyusul dengan bobot 95. Dalam Zona 2 ada 3 master (6\%), 1 (2\%) ahli, 8 (16\%) cakap, 14 (28\%) mampu dan 24 (48\%) pemula. ASN pada Zona 4 memiliki bobot kemampuan multimedia 89 . Zona 4 memiliki 1 (2\%) master, 1 (2\%) ahli, 8 (16\%) cakap, 16 (32\%) mampu dan 24 (48\%) pemula. Bobot kemampuan multimedia yang paling rendah adalah zona 3 yang berjumlah 87 , dengan seorang (2\%) master, 2 ahli (4\%), 8 (16\%) cakap, 11 (22\%) mampu, serta 28 (56\%) pemula.

Sesuai pengukuran kompetensi Software Development, sebanyak 150 responden (75\%) ASN Bidang TIK menyatakan masih berada pada level pemula. Responden yang mampu mengerjakan jenis 
pekerjaan tersebut sebanyak 40 responden (20\%), sementara yang cakap hanya berjumlah 10 responden $(5 \%)$, dan tidak ada yang ahli maupun yang master $(0 \%)$.

Jika dirinci berdasarkan zona sebagaimana disajikan dalam Gambar 6, kemampuan jaringan komputer ASN bidang TIK pemerintah provinsi di wilayah kerja BBPSDMP Kominfo Makassar, adalah bobot 66 pada Zona 1 dan Zona 2, serta bobot 64 pada Zona 3 dan Zona 4 . Pada Zona 1, tidak ada master maupun ahli dalam kompetensi Software Development, namun ada 5 yang cakap (10\%), 6 yang mampu (12\%) dan 39 yang pemula (78\%). Demikian pula pada Zona 2, tidak ada yang master maupun yang ahli, yang ada hanya 2 (4\%) yang cakap, 12 (24\%) yang mampu dan $36(72 \%)$ pemula. Tidak terdapat master dan ahli pada Zona 3, melainkan 1 (2\%) yang cakap, 12 (24\%) yang mampu dan 37 (74\%) pemula. Sama dengan zona lain, pada Zona 3 juga tidak terdapat ASN bidang TIK yang master dan ahli dalam software development, melainkan $2(4 \%)$ yang cakap, 10 (20\%) yang mampu dan 38 (76\%) pemula.

Sesuai pengukuran kompetensi system manajemen data, sebanyak 97 responden (48,5\%) ASN bidang TIK menyatakan masih berada pada level pemula dalam mengerjakan jenis pekerjaan sistem manajemen data. Responden yang mampu mengerjakan jenis pekerjaan tersebut sebanyak 68 responden (34\%), sementara yang cakap hanya berjumlah 22 responden (1\%), yang ahli hanya 8 responden (4\%), dan hanya 5 responden $(2,5 \%)$ yang master.

\section{Gambar 6. Kompetensi Software Development ASN bidang TIK (sumber: hasil olah data).}

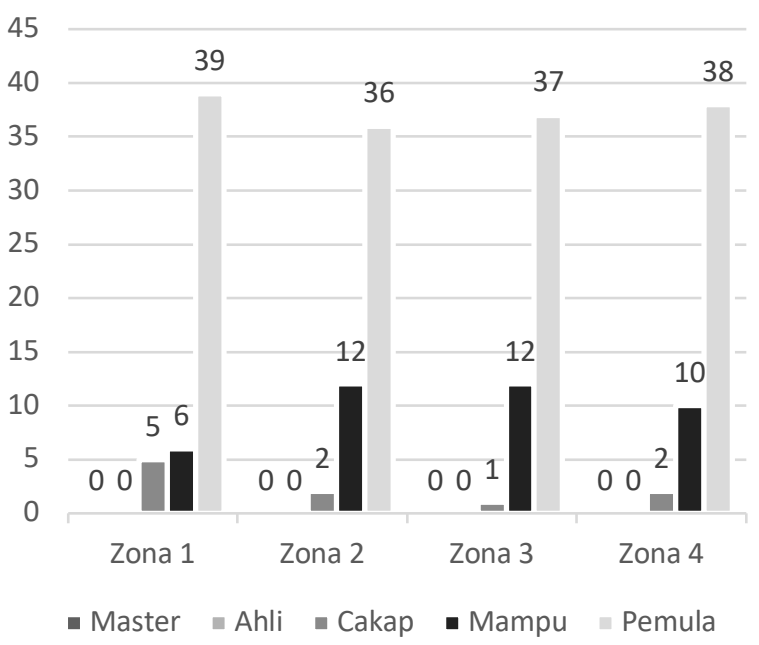

Jika dirinci berdasarkan zona sebagaimana disajikan dalam Gambar 7, kemampuan sistem manajemen data ASN bidang TIK yang tertinggi ada di pada Zona 1 dengan bobot 92, dengan rincian $1(2 \%)$ master, 2 (4\%) ahli, 8 (16\%) cakap, 16 (32\%) mampu dan 23 (46\%) pemula. Zona 
2 menyusul dengan bobot 90. Zona 2 memiliki $2(4 \%)$ master, $1(2 \%)$ ahli, 7 (14\%) cakap, 15 (30\%) mampu dan 25 (5034\%) pemula. ASN pada Zona 3 memiliki bobot kemampuan pengoperasian komputer 88. Zona 3 memiliki 1 (2\%) master, 3 (6\%) ahli, $3(6 \%)$ cakap, 19 (38\%) mampu dan $24(48 \%)$ pemula. Bobot kemampuan sistem manajemen data yang paling rendah adalah zona 4 yang hanya mencapai 86 , dengan seorang master $(2 \%)$, 2 (4\%) ahli, 4 (8\%) cakap, dan $18(36 \%)$ mampu dan $25(50 \%)$ pemula.

\section{Gambar 7. Kompetensi Sistem Manajemen Data ASN Bidang TIK (sumber: hasil olah data).}

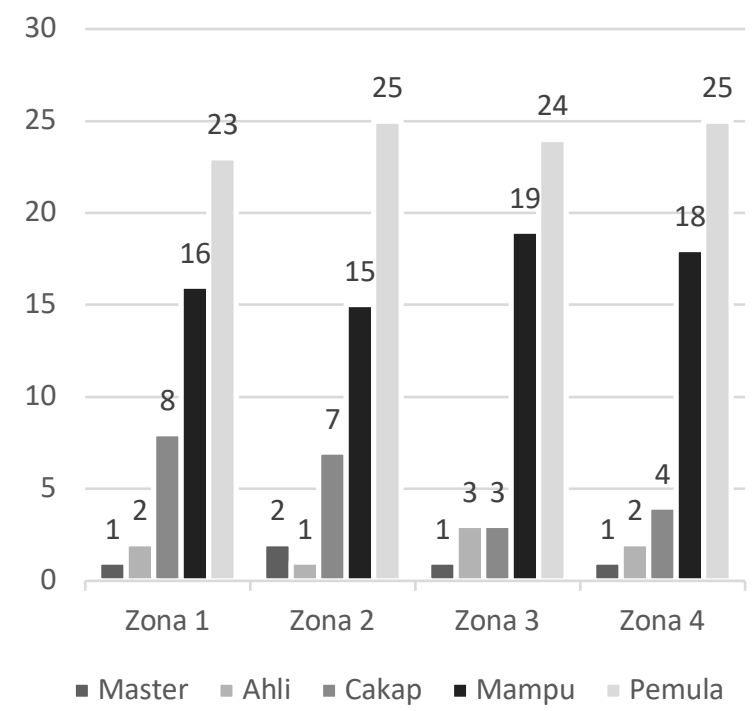

\section{ASN Bidang Kehumasan}

Berdasarkan survey yang dilakukan pada sampel, yakni 80 ASN bidang kehumasan di empat provinsi, diketahui bahwa SDM bidang kehumasan berlatar pendidikan S1 sebesar 35 orang $(43,8 \%)$,
S2 berjumlah 27 orang (33,8\%), SLTA berjumlah 17 orang (21,3\%), Diploma 1 orang (1,3\%), dan belum ada yang S3 (0\%).

Jika diurutkan berdasarkan usia, ASN Bidang Kehumasan yang terbanyak adalah ASN yang berusia 31-40 tahun, yakni sebanyak 28 responden (35\%). Yang terbanyak kedua adalah yang berusia 41-50 tahun, yakni 24 responden (30\%). Yang senior, yakni yang berusia 51 tahun ke atas dengan jumlah 18 responden (22,5\%) adalah jumlah urutan ketiga. ASN bidang kehumasan yang paling sedikit jumlahnya adalah yang berusia 30 tahun ke bawah, yakni hanya 10 responden $(12,5 \%)$.

Berdasarkan survey, diketahui pula bahwa sebagian besar ASN yang ditugaskan untuk mengerjakan pekerjaan kehumasan adalah Fungsional Umum, yakni sebanyak 49 responden $(61,25 \%)$. Pejabat Struktural yang diberi tugas/fungsi di bidang kehumasan berjumlah 29 responden (36,25\%). Sementara itu, Pejabat Fungsional Tertentu yang bertindak sebagai tenaga Kehumasan hanya berjumlah 2 responden (2,5\%).

Pengalaman para responden ditugaskan dalam bidang kehumasan beragam. Ada yang bertugas kurang dari satu tahun, hingga yang di atas 10 tahun. ASN yang memiliki pengalaman kerja di bidang kehumasan 1-2 tahun adalah yang terbanyak dengan jumlah 25 responden $(31,25 \%)$. Sementara itu, yang memiliki 
pengalaman 3-5 tahun berjumlah 21 responden (26,25\%), yang memiliki pengalaman di bawah 1 tahun berjumlah 14 responden (17,5\%), lebih banyak jumlahnya daripada yang telah berpengalaman 6-10 tahun, yaitu 12 responden $(15 \%)$ dan yang berpengalaman lebih dari 10 tahun, yakni 8 responden $(10 \%)$.

Berdasarkan survey, 46 responden (57,5\%) menggunakan aplikasi pengolah kata, 24 responden $(30 \%)$ menggunakan aplikasi pengolah angka dan 18 responden $(22,5 \%)$ menggunakan aplikasi pengolah presentasi. Sementara itu, pengguna aplikasi desain hanya 10 responden (12,5\%), aplikasi multimedia sebanyak 8 responden $(10 \%)$, aplikasi pemrograman sebanyak 6 responden $(7,5 \%)$, dan aplikasi lainnya, seperti sistem informasi kepegawaian, dan lain-lain sebanyak 9 responden $(11,25 \%)$.

UU ASN mengamanatkan bahwa setiap pegawai memiliki hak dan kesempatan untuk mengembangkan kompetensi, yakni meliputi kompetensi teknis yang diukur dari tingkat dan spesialisasi pendidikan, pelatihan teknis fungsional, dan pengalaman bekerja secara teknis. Berdasarkan survey, dua per tiga ASN bidang Kehumasan pada pemerintah daerah provinsi yang diteliti $(66,83 \%)$ tidak pernah mengikuti pelatihan bidang kehumasan. Hal ini sejalan dengan kepemilikan sertifikat kompetensi bidang kehumasan yang baru mencapai $12,15 \%$.

Berdasarkan hasil FGD, para pengelola ASN pronvisi di wilayah penelitian menyatakan belum sanggup memenuhi kebutuhan Diklat. Berdasarkan Survey, pelatihan yang paling banyak diinginkan oleh ASN bidang kehumasan adalah pelatihan Communications skill. Sebanyak $36 \quad(45 \%)$ responden menyampaikan keinginannya untuk mendapat pelatihan tersebut. Selain itu, 28 responden (35\%) responden ingin mendapat pelatihan public relation, 27 responden $(33,75 \%)$ ingin mendapat pelatihan public speaking dan 22 responden $(27,5 \%)$ ingin mendapat pelatihan protokoler. Peminat pelatihan menulis dan media relation ada, tetapi tidak terlalu banyak, hanya 17 (21,25\%) dan 14 (17,5\%) responden. Yang berminat mengikuti pelatihan jurnalistik berjumlah 12 responden $(15 \%)$, dan 9 responden $(11,25)$ berharap bisa mengikuti pelatihan Bahasa Inggris. Sementara itu, 7 responden $(8,75)$ menginginkan pelatihan lain, seperti: graphic desing, computer programming, kearsipan, dan administrasi.

Gambar 8. Kompetensi rata-rata ASN Kehumasan (sumber: hasil olah data). 
3

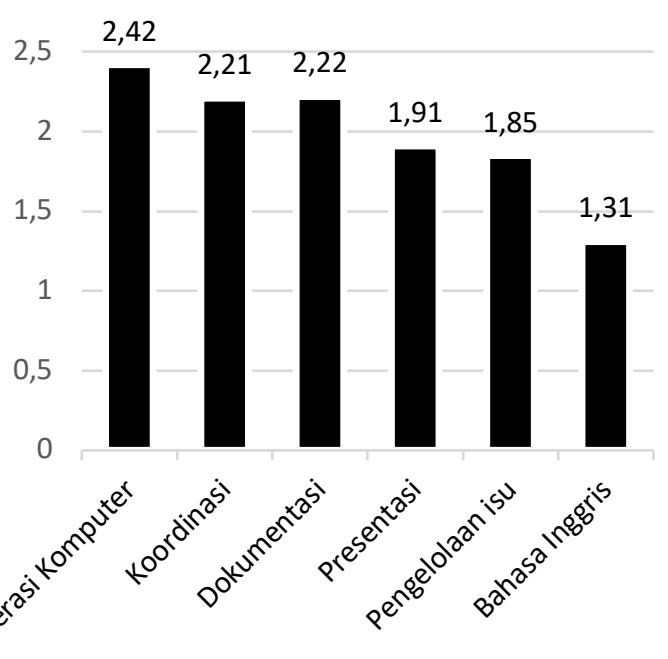

Melalui Gambar 8, dapat dilihat bahwa tidak terdapat perbedaan signifikan kemampuan rata-rata ASN Bidang Kehumasan dalam mengerjakan jenis-jenis pekerjaan kehumasan, kecuali Bahasa Inggris. Skor kemampuan mereka berkisar antara 1,3 - 2,4. Hal tesebut menunjukkan bahwa secara rata-rata, mereka berada pada level pemula (level 1), hingga sedikit di atas level mampu (level 2).

Mereka memiliki skor kemampuan 2,42 dalam jenis keahlian operasi komputer. Untuk keahlian dokumentasi dan koordinasi mereka memiliki kemampuan rata-rata dengan skor 2,22 dan 2,21. Dalam hal presentasi, skor mereka belum memasuki level mampu, karena baru mencapai skor 1,91. Demikian pula kemampuan rata-rata mereka dalam pengelolaan isu, baru 1,85. Mereka mengakui lemah dalam Bahasa Inggris dan menilai diri mereka sendiri secara rata-rata dengan skor 1,31 .
Berdasarkan survey, sebanyak 29 responden $(36,25 \%)$ ASN Bidang Kehumasan menyatakan berada pada level mampu mengerjakan jenis pekerjaan operasi komputer, sementara 26 responden $(32,5 \%)$ masih pemula. Responden yang memandang dirinya cakap mengerjakan jenis pekerjaan tersebut mencapai 18 responden $(22,5 \%)$, sementara yang ahli hanya 4 responden $(5 \%)$ dan yang master hanya 3 responden $(3,75 \%)$.

Gambar 9. Kompetensi pengoperasian Komputer ASN Kehumasan (sumber: hasil olah data).

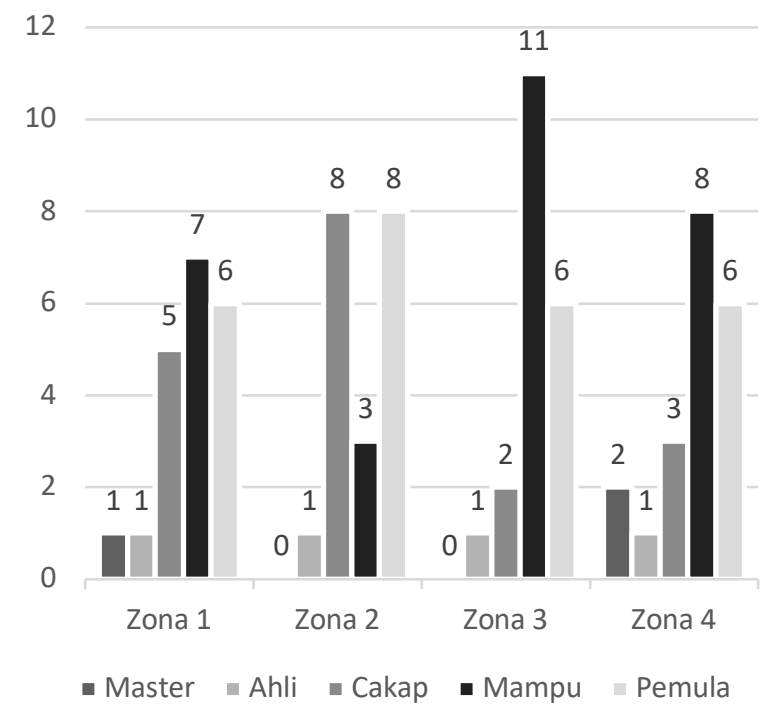

Jika dirinci berdasarkan zona sebagaimana disajikan dalam Gambar 9, kemampuan mengoperasikan komputer ASN bidang kehumasan yang tertinggi ada di pada Zona 4 dengan bobot 45, dengan rincian $2(10 \%)$ master, $1(5 \%)$ ahli, 3 (15\%) cakap, 8 (40\%) mampu dan $6(30 \%)$ pemula. 
Zona 1 menyusul dengan bobot 44 . Zona 1 memiliki 1 (5\%) master, 1 (5\%) ahli, 5 (25\%) cakap, 7 (35\%) mampu dan 6 (30\%) pemula. ASN pada Zona 2 memiliki bobot kemampuan aplikasi perkantoran 42 . Zona 2 tidak memiliki master (0\%), 1 (5\%) ahli, 8 (40\%) cakap, 3 (15\%) mampu dan 8 (40\%) pemula. Bobot kemampuan operasi komputer ASN Bidang Kehumasan yang paling rendah adalah zona 3 yang hanya mencapai 38, tanpa seorang pun master $(0 \%), 1(5 \%)$ ahli, $2(10 \%)$ cakap, dan masing-masing 11 (55\%) mampu dan 6 (30\%) pemula.

Berdasarkan hasil pengukuran kompetensi koordinasi, sebanyak 34 responden $(42,5 \%) \quad$ ASN bidang kehumasan menyatakan berada pada level mampu, sementara 31 responden $(38,75 \%)$ masih pemula. Responden yang memandang dirinya cakap mengerjakan jenis pekerjaan tersebut mencapai 10 responden $(12,5 \%)$, sementara yang ahli hanya 4 responden $(5 \%)$ dan yang master hanya 1 responden $(1,25 \%)$.

Jika dirinci berdasarkan zona sebagaimana disajikan dalam Gambar 10, kemampuan koordinasi ASN bidang kehumasan yang tertinggi ada di pada Zona 4 dengan bobot 41 , dengan rincian 1 (5\%) master, 1 (5\%) ahli, 2 (10\%) cakap, 10 $(50 \%)$ mampu dan $6(30 \%)$ pemula. Zona 2 menyusul dengan bobot 40 . Zona 2 tidak memiliki seorang pun master $(0 \%), 1(5 \%)$ ahli, $6(30 \%)$ cakap, $5(25 \%)$ mampu dan 8 (40\%) pemula. ASN pada Zona 3 memiliki bobot kemampuan aplikasi perkantoran 38 . Zona 3 tidak memiliki master $(0 \%)$, terdapat $1(5 \%)$ ahli, $3(15 \%)$ cakap, 9 (45\%) mampu dan 7 (35\%) pemula. Bobot kemampuan koordinasi ASN Bidang Kehumasan yang paling rendah adalah zona 1 yang hanya mencapai 36 , tanpa seorang pun master $(0 \%)$, memiliki $1(5 \%)$ ahli, 4 (20\%) cakap, dan masing-masing 5 (25\%) mampu dan $10(50 \%)$ pemula.

\section{Gambar 10. Kompetensi Koordinasi ASN Kehumasan (sumber: hasil olah data).}

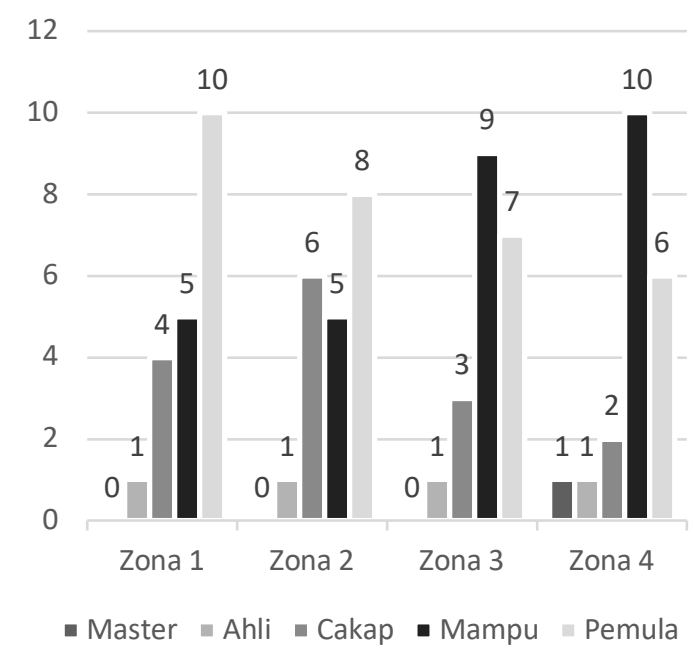

Berdasarkan survey, sebanyak 32 responden (40\%) ASN Bidang Kehumasan menyatakan berada pada level mampu melakukan pekerjaan dokumentasi, sementara 29 responden $(36,25 \%)$ masih pemula. Responden yang memandang dirinya cakap mengerjakan jenis pekerjaan tersebut mencapai 14 responden $(17,5 \%)$, 
sementara yang ahli hanya 5 responden $(6,25 \%)$ dan tidak ada yang mengaku master $(0 \%)$. Jika dirinci berdasarkan zona sebagaimana disajikan dalam Gambar 11, kemampuan dokumentasi ASN bidang Kehumasan yang tertinggi ada di pada Zona 2 dengan bobot 42. Tidak ada master dokumentasi dalam zona ini, namun terdapat $3(15 \%)$ ahli, $4(20 \%)$ cakap, 5 (25\%) mampu dan $8(40 \%)$ pemula.

\section{Gambar 11. Kompetensi Dokumentasi ASN Kehumasan (sumber: hasil olah data).}

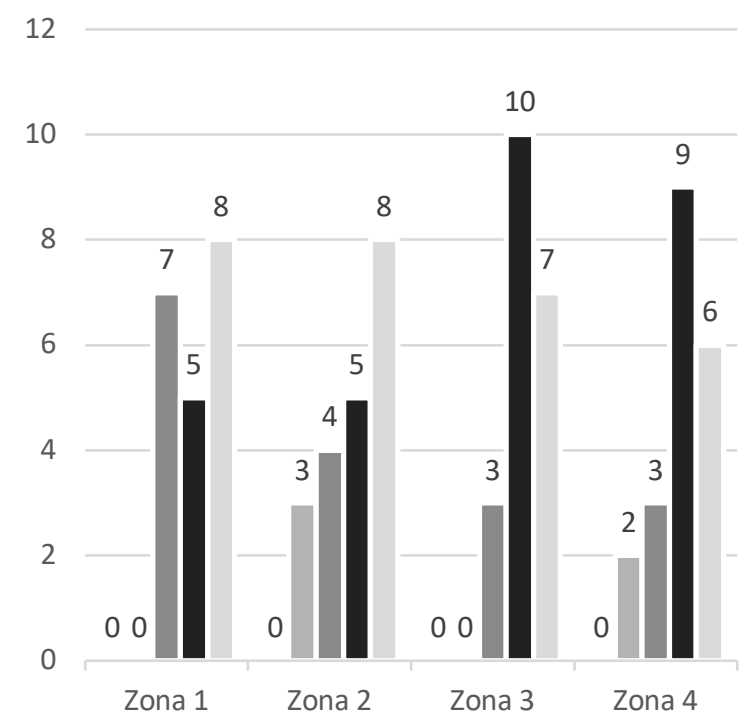

Zona 4 menyusul dengan bobot 41 .

Zona 4 juga tidak memiliki seorang pun master $(0 \%)$, namun ada $2(10 \%)$ ahli, 3 (15\%) cakap, 9 (45\%) mampu dan $6(30 \%)$ pemula. ASN pada Zona 1 memiliki bobot kemampuan dokumentasi 39. Zona 1 tidak memiliki master dan ahli (0\%), namun ada 7 (35\%) yang cakap, 5 (25\%) yang mampu dan $8(40 \%)$ yang pemula. Bobot kemampuan dokumentasi ASN Bidang
Kehumasan yang paling rendah adalah Zona 3 yang hanya mencapai 36, tanpa seorang pun master dan ahli ( $0 \%)$, memiliki 3 (15\%) yang cakap, dan masing-masing 10 (50\%) yang mampu dan 7 (35\%) yang pemula.

Sebanyak 44 responden (55\%) ASN Bidang kehumasan menyatakan masih pemula dalam melakukan pekerjaan presentasi, sementara responden yang memandang dirinya mampu mengerjakan jenis pekerjaan tersebut mencapai 25 responden $(31,25 \%)$, sementara yang cakap mencapai 9 responden $(11,25 \%)$, dan yang ahli hanya 2 responden $(2,5 \%)$ dan tidak ada yang mengaku master $(0 \%)$.

Jika dirinci berdasarkan zona sebagaimana disajikan dalam Gambar 12, kemampuan presentasi/publikasi ASN bidang Kehumasan yang tertinggi ada di pada Zona 4 dengan bobot 34 . Tidak ada master presentasi/publikasi dalam zona ini, namun terdapat 1 (5\%) ahli, $2(10 \%)$ cakap, 7 (35\%) mampu dan 10 (50\%) pemula. Zona 2 dan 3 menyusul dengan bobot 33 . Zona 2 juga tidak memiliki seorang pun master $(0 \%)$, bahkan tidak ada yang ahli, namun ada 4 (20\%) cakap, 5 (25\%) mampu dan $11(55 \%)$ pemula. Zona 3 tidak memiliki master $(0 \%)$, namun ada 1 yang ahli (5\%), 2 (10\%) yang cakap, 6 (30\%) yang mampu dan 11 (55\%) yang pemula.

Bobot kemampuan presentasi/publikasi ASN Bidang 
Kehumasan yang paling rendah adalah Zona 1 yang hanya mencapai 29, tanpa seorang pun master dan ahli $(0 \%)$, ada 1 $(5 \%)$ yang cakap, $7 \quad(35 \%)$ yang menyatakan mampu, dan $12(60 \%)$ yang pemula.

Sebanyak 44 responden (55\%) ASN Bidang Kehumasan menyatakan masih pemula dalam melakukan pekerjaan pengelolaan isu, sementara responden yang memandang dirinya mampu mengerjakan jenis pekerjaan tersebut mencapai 23 responden $(28,75 \%)$, yang cakap mencapai 11 responden $(13,75 \%)$, dan yang ahli hanya 2 responden $(2,5 \%)$ dan tidak ada yang mengaku master $(0 \%)$.

\section{Gambar 12. Kompetensi Presentasi ASN Kehumasan (sumber: hasil olah data).}

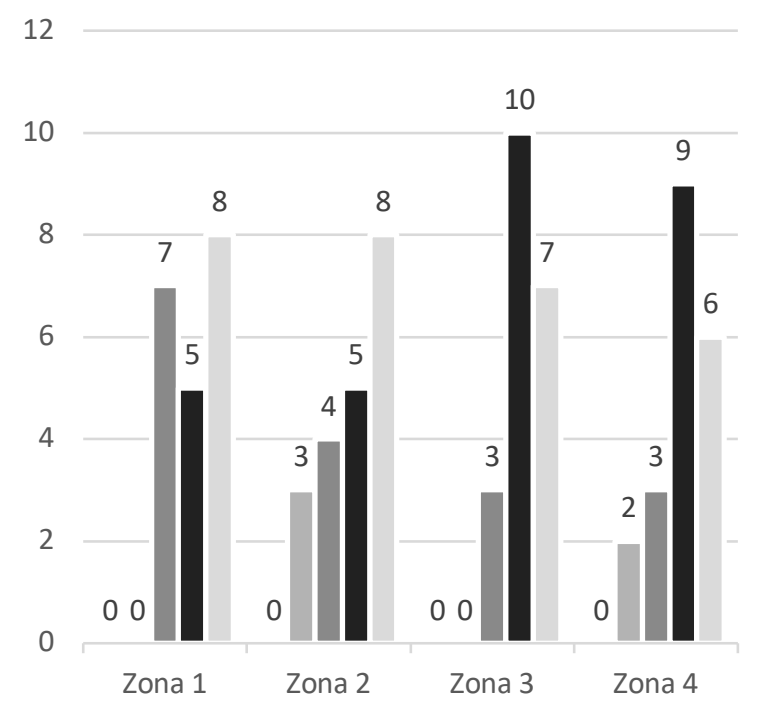

Jika dirinci berdasarkan zona sebagaimana disajikan dalam Gambar 13, kemampuan pengelolaan isu ASN bidang Kehumasan yang tertinggi ada di pada Zona
4 dengan bobot 35 . Tidak ada master pengelolaan isu dalam zona ini, namun terdapat $1(5 \%)$ ahli, $2(10 \%)$ cakap, 8 (40\%) mampu dan 9 (45\%) pemula. Zona 2 menyusul dengan bobot 33. Zona 2 juga tidak memiliki seorang pun master dan ahli (0\%), namun ada $5(25 \%)$ yang cakap, 3 (15\%) yang mampu dan $12(60 \%)$ pemula. Selanjutnya, ASN pada Zona 3 memiliki bobot kemampuan pengelolaan isu 32 .

\section{Gambar 13. Kompetensi Pengelolaan Isu} ASN Kehumasan (sumber: hasil olah data).

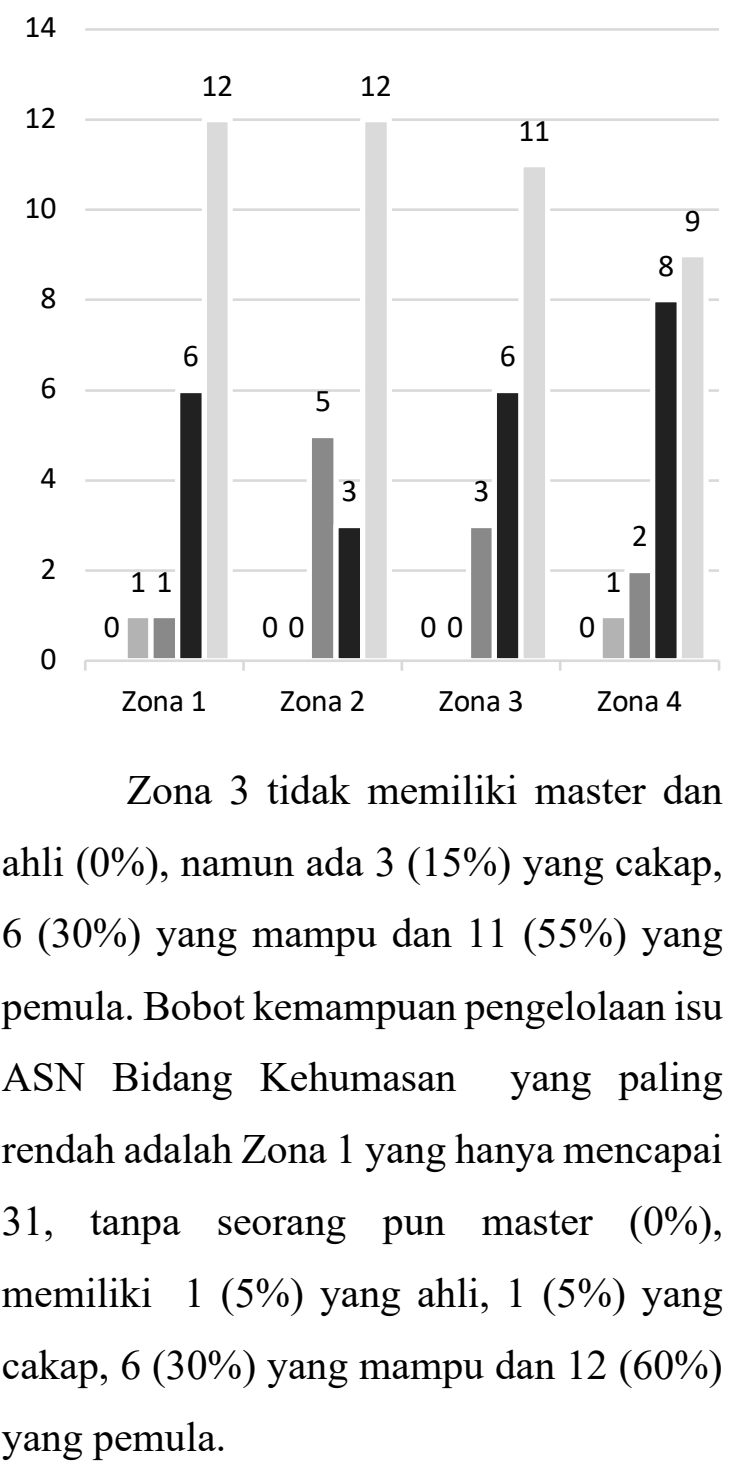


Sebanyak 64 orang $(80 \%)$ ASN Bidang kehumasan menyatakan masih pemula dalam melakukan Bahasa Inggris, sementara responden yang memandang dirinya mampu mengerjakan jenis pekerjaan tersebut hanya 13 responden $(16,25 \%)$, yang cakap hanya 3 responden (3,75\%). Tidak ada satu pun ASN bidang Kehumasan yang mengaku sebagai ahli maupun master (0\%) dalam Bahasa Inggris.

Berdasarkan zona, sebagaimana disajikan dalam Gambar 14, kemampuan Bahasa Inggris ASN bidang Kehumasan yang tertinggi ada di pada Zona 3 dengan bobot 28. Tidak ada yang menilai dirinya sebagai master maupun ahli Bahasa Inggris dalam zona ini, namun terdapat $2(10 \%)$ yang cakap, 4 (20\%) yang mampu dan 14 $(70 \%)$ pemula. Zona 4 menyusul dengan bobot 26. Zona 4 juga tidak memiliki seorang pun master maupun ahli $(0 \%)$, namun ada 1 (5\%) yang cakap, 4 (20\%) yang mampu dan 15 (75\%) pemula.

Gambar 14 Kompetensi Bahasa Inggris ASN Kehumasan (sumber: hasil olah data).

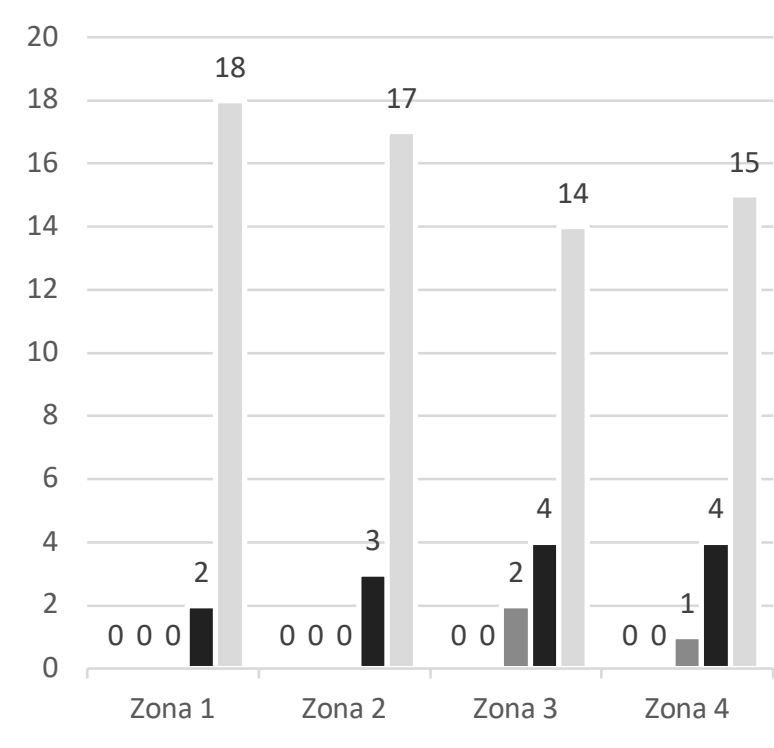

Selanjutnya, ASN pada Zona 2 memiliki bobot kemampuan Bahasa Inggris 23. Zona 2 juga tidak memiliki master, ahli dan yang cakap $(0 \%)$, namun ada $3(15 \%)$ yang mampu dan 17 (85\%) yang pemula. Bobot kemampuan Bahasa Inggris ASN Bidang Kehumasan yang paling rendah adalah pada Zona 1 yang hanya mencapai 22 , tanpa seorang pun master, ahli dan yang cakap (0\%), memiliki 2 responden $(10 \%)$ yang mampu dan 18 (80\%) yang pemula.

\section{Upaya Pengembangan Kompetensi ASN}

Rencana

pengembangan

kompetensi ASN bidang TIK dan Kehumasan tidak termasuk dalam rencana pemerintah provinsi yang diteliti. Hal tersebut terungkap dalam seluruh FGD yang dilakukan. Ketika diajukan pertanyaan mengenai keberadaan rencana strategis pemerintah daerah dalam pembangunan TIK dan Kehumasan, para narasumber FGD serempak mengatakan 
belum ada. Ada dari kalangan pengelola ASN di provinsi yang lebih mengharapkan pegawai baru atau mutasi pegawai yang mumpuni dibandingkan meningkatkan kapasitas pegawai yang sudah ada, narasumber tersebut mengatakan: "Perlu menyiapkan SDM melalui perekrutan pegawai yang memiliki kompetensi khusus." Narasumber lainnya mengatakan: "Belum ada rencana strategis terkait pengembangan SDM TIK. Berdasarkan informasi, (Ada Dinas yang) sudah meminta penambahan SDM yang punya kemampuan di bidang TIK ke BKD setempat, namun belum ada juga. BKN menyampaikan bahwa SDM TIK yang berstatus ASN/PNS tersebar tidak merata di beberapa OPD/Satker. Ada kendala saat ingin memindahkan seseorang ke satker lainnya, yaitu keengganan PNS dan kendala lainnya. Sementara untuk penambahan (pegawai), memang masih menunggu kabar terkait kuota yang di berikan. Diharapkan, OPD segera mengusulkan kebutuhan SDM nya agar bisa terakomodir secepatnya untuk perekrutan pegawai di tahun 2019."

Meskipun demikian, sebenarnya sudah sedikit rencana upaya untuk merangsang kinerja baik ASN, seperti forum, apresiasi, dan diklat, sebagaimanan diungkapkan oleh Narasumber FGD di Sulawesi Selatan:" Telah diadakan rapat koordinasi para petugas humas yang telah dibentuk dalam forum humas ekspo. Sebagai langkah awal, diadakan perlombaan humas terbaik melalui humas ekspo bagi OPD propinsi maupun kabupaten kota. Rencananya akan dilakukan diklat kehumasan dalam waktu dekat." Sayang, hampir semua informan merasa tidak pernah diberi apresiasi terhadap kinerja mereka. Ketika ditanyakan tentang reward, ada informan yang mengatakan: "big no!" Di sisi lain, salah satu ASN dari Papua yang pernah menerima sertifikat sudah merasa kinerjanya telah diapresiasi oleh pemerintah. Informan lain mengaku bahwa diberi tugas perjalanan dinas juga termasuk apresiasi kinerja. Ada pula yang merasa semangat karena diberikan ucapan selamat. Rangsangan agar pegawai semangat, juga merupakan salah satu cara meningkatkan kompetensi ASN, sebab dengan semangat yang dimiliki, walaupun dengan fasilitas yang minim, ASN berusaha belajar mandiri untuk dapat mengerjakan tugas dengan baik. Hal tersebut dibuktikan dengan pengakuan para informan yang banyak belajar secara otodidak untuk menyelesaikan pekerjaan yang ditanggungjawabkan pada mereka.

\section{Kebutuhan Peningkatan Kompetensi} ASN

Pemerintah provinsi memerlukan peta ASN yang telah mengikuti pelatihan, 
sebab telah terungkap dalam FGD di Provinsi Papua, salah satu narasumber menyatakan: "Belum ada data yang jelas pegawai yang sudah mengikuti pelatihan TIK." Narasumber yang sama juga mengungkapkan bahwa ia menemukan ASN yang sudah terlatih tidak bersedia membagi ilmunya ke rekan-rekan yang lain, oleh karena itu mungkin pemerintah provinsi memerlukan tenaga-tenaga pembimbing bidang TIK dan Kehumasan untuk seluruh ASN bidang tersebut. Selain itu, dalam FGD di Papua juga terungkap bahwa sudah banyak ASN mengikuti pelatihan, tetapi belum bisa mengaplikasikan hasil pelatihannya, sebab model pelatihan yang diikuti sangat singkat dan sifatnya masih pengenalan. Hal ini menunjukkan bahwa pemerintah provinsi memerlukan perencanan serta pelaksanaan pendidikan dan latihan yang bertahap dan berkelanjutan. Selain itu, permasalahan anggaran sangat sering menjadi alasan bagi pemerintah provinsi atas permasalahan rendahnya kompetensi ASN. Menurut beberapa narasumber FGD, Pemerintah Pusat sangat diharapkan untuk membantu menyelesaikan permasalahan tersebut, misalnya dengan menambah frekuensi Diklat dan Bimtek di daerah-daerah dengan biaya Pemerintah Pusat, memberikan beasiswa kepada ASN daerah, atau menyediakan tenaga-tenaga pendamping/perwakilan di daerah yang dapat dijadikan rujukan bagi ASN di provinsi masing-masing.

\section{KESIMPULAN}

Kebanyakan ASN bidang TIK dan Kehumasan Provinsi yang diteliti memiliki jenjang pendidikan S1. Sayang, jurusan kesarjanaan mereka banyak yang tidak sejalan dengan tugas bidang TIK dan kehumasan. ASN bidang TIK didominasi yang berusia muda, yakni di bawah 40 tahun, sementara sebararan usia ASN kehumasan relatif merata dari yang berumur 31 hingga 50 tahun atas. Mayoritas, ASN yang bertugas di bidang TIK maupun kehumasan adalah Fungsional Umum. Jumlah ASN TIK yang memiliki pengalaman 1-2 tahun, 3-5 tahun dan 6-10 tahun adalah mayoritas dengan porsi yang relatif merata, sementara jumlah ASN Kehumasan yang mayoritas adalah yang memiliki pengalaman 1-2 tahun dan 3-5 tahun. Kebanyakan ASN TIK mengerjakan pekerjaan Perkantoran, dengan menggunakan aplikasi pengolah kata dan angka dan presentasi. Sementara itu, ASN yang mengerjakan pekerjaan kehumasan dominan menggunakan aplikasi pengolah kata. Lebih dari setengah ASN dalam dua bidang tersebut belum pernah mengikuti pelatihan dalam bidang masing-masing, sehingga minim dari mereka yang memiliki sertifikat kompetensi. 
Kemampuan TIK dan kehumasan ASN Provinsi Sulawesi Selatan, Sulawesi Tenggara, Maluku dan Papua cukup merata, yakni rata-rata berada di level pemula hingga sedikit di atas level mampu. Meskipun demikian, jika dirinci, ada juga puluhan yang mengaku master, ahli, dan cakap dalam suatu jenis keahlian. Jumlah yang terbanyak adalah yang pemula, kemudian yang mampu, yang cakap, yang ahli, dan yang tersedikit adalah yang master. Upaya-upaya peningkatan kompetensi ASN bidang TIK dan kehumasan telah dilakukan oleh pengelola ASN pemerintah provinsi yang diteliti dalam bentuk perlombaan bidang Humas, dan beberapa pelatihan, namun jumlah dan cakupannya masih minim. ASN bidang TIK dan humas telah berusaha untuk dapat bekerja dengan baik. Mereka bahkan belajar secara otodidak untuk hal-hal yang belum dikuasai sebelumnya. Pemerintah Provinsi yang diteliti mengaku membutuhkan dukungan dari pemerintah pusat dalam rangka meningkatkan kemampuan TIK dan Kehumasan ASN. Pemerintah pusat dapat mendukung dari segi pengelolaan, maupun anggaran.

ASN yang mayoritas adalah para sarjana, namun tidak sejalan dengan tugas TIK maupun Kehumasan perlu ditingkatkan pengetahuan dan keterampilan TIK dan kehumasannya untuk menjawab tantangan jaman yang menuntut kinerja serba cepat dan tepat. Usia ASN yang relatif masih muda menyimpan potensipotensi untuk menjawab tantangan jaman, maka ASN tersebut perlu dibina, tidak hanya kompetensi, namun juga semangat kerjanya. Pemerintah Pusat dapat membantu meningkatkan kompetensi ASN provinsi bidang TIK dan Kehumasan dengan cara memberikan diklat dan bimtek dengan biaya pemerintah pusat, menyediakan pendamping/trainer sebagai rujukan ASN di daerah, membantu perencanaan dan realisasi diklat, dan kegiatan peningkatan kompetensi lain. ASN juga dapat didorong agar melakukan pengembangan diri dan tidak sunkan untuk berbagi pengetahuan agar kinerja institusi masing-masing semakin baik.

\section{REFERENSI}

Rencana Aksi Nasional Keterbukaan Pemerintah 2016-2017, (2016). http://www.opengovpartnership.org/sit es/default/files/31102016_Renaksi OGI 2016-2017.pdf

Batita, A., Nayoan, H., \& Tompodung, J. (2017). Peranan Badan Kepegawaian Daerah dalam Penempatan Jabatan Aparatur Sipil Negara di Lingkungan Dinas Pendidikan Kabupaten Halmahera Barat. Jurnal Eksekutif, 2(2), $\quad$ 1-9. https://ejournal.unsrat.ac.id/index.php/j urnaleksekutif/article/view/17407

Creswell, J. W. (2015). A Concise Introduction to Mixed Methods Research (V. Knight (ed.)). Sage.

Haryati, H. (2017). Studi Literasi Informasi 
pada Pegawai Negeri Sipil (PNS) Tenaga Pendidik. Jurnal Penelitian Komunikasi, 14(2), 111-126. https://doi.org/10.20422/jpk.v14i2.172

Heryanto, G. G. (2018). Tambahan Armada Komunikasi Istana. Media Indonesia. http://m.mediaindonesia.com/read/detai 1/162923-tambahan-armadakomunikasi-istana

Juditha, C. (2018). Hoax Communication Interactivity in Social Media and Anticipation (Interaksi Komunikasi Hoax di Media Sosial serta Antisipasinya). Journal Pekommas, 3(1), 31-44. https://doi.org/10.30818/jpkm.2018.20 30104

Kusumawati, A., Dawud, J., \& Gedeona, H. T. (2019). Pemodelan Data Center untuk Efektivitas Pelayanan Publik Berbasis TIK di Pemerintah Kota Bandung. Konferensi Nasional Ilmu Administrasi, 1-8. http://180.250.247.102/conference/inde x.php/knia/index

Lauranti, M., Afrina, E., Mawesti, D., Cahyanto, A., Handoko, A. S., Huda, A. S., Nurrahmah, B., Ariadi, E., Surianto, F., Maulana, M., Vonika, N., Maarif, S., \& Zulkifli. (2017). Open Government : Mengkaji Penggunaan e-Government Pemerintah Daerah di Indonesia (Sebuah Laporan untuk Advokasi Kebijakan Implementasi e-Government ).

http://theprakarsa.org/new/in/reports/de tail/17/Open-Government-MengkajiPenggunaan-e-Government-

Pemerintah-Daerah-di-Indonesia

Maryati, S. (2015). Dinamika Pengangguran Terdidik: Tantangan Menuju Bonus Demografi di Indonesia. Economica, 3(2), 124-136. https://doi.org/10.22202/economica.20 15.v3.i2.249

Mukhroman, I., Gumelar, R. G., \& Ahmad, I.
(2014). Permasalahan, Solusi dan Model Komunikasi Humas dalam Pengembangan Kawasan Ekonomi Khusus Pariwisata Tanjung Lesung. Pekommas, 17(3), 169-180. https://doi.org/2502-1907

Prasetyo, R. B., \& Firdaus, M. (2009). Pengaruh Infrastruktur pada Pertumbuhan Ekonomi Wilayah di Indonesia. Jurnal Ekonomi Dan Kebijakan Pembangunan, 2(2), 222236.

Sachs, J. D. (2015, May). Data for development. Project Syndicate: The World's Opinion Page, May. https://www.projectsyndicate.org/commentary/sustainabledevelopment-data-by-jeffrey-d-sachs2015-05?barrier=accesspaylog

Sisil. (2017). Peringkat E-Government Berdasarkan Survey PBB. Sistem Informasi IT Telkom Purwokerto. http://si.st3telkom.ac.id/2017/06/06/per ingkat-e-government-berdasarkansurvey-pbb/

Siswanto, E. (2020). Persepsi Kesesuaian Penempatan Pegawai Dalam Menunjang Peningkatan Kinerja BBPK Ciloto Tahun 2020. JARTIKA Jurnal Riset Teknologi Dan Inovasi Pendidikan, 3(2), 312-321. https://doi.org/10.36765/jartika.v3i2.26 9

Suroto, H. (2017). Menumbuhkembangkan Budaya Literasi Kalangan Pegawai Negeri Sipil di Papua. Jurnal Jarlitbang Pendidikan, 3(2), 319-327. http://www.journal.kelitbanganwonogir i.org/index.php/jjp/article/view/79

Syahputra, I. (2017). Demokrasi Virtual dan perang Siber di Media Sosial: perspektif Netizen Indonesia. Jurnal ASPIKOM, 3(3), 457-475. https://doi.org/10.24329/aspikom.v3i3. 141 
Widowati, D. P. D. (2017). Urgensi

Pengembangan SDM Bidang TIK untuk ASN di Seluruh Indonesia. BPPTIK. https://bpptik.kominfo.go.id/2017/04/0 3/3044/urgensi-pengembangan-sdmbidang-tik-untuk-asn-di-seluruh- indonesia/

Yamane, T. (1973). Statistics: An introductory analysis. Third edition Harper International edition. New York 